\title{
Mobile Based Decision Support System of Supplier Evaluation
}

\author{
https://doi.org/10.3991/ijim.v14i04.11371 \\ Faried Effendy \\ Universitas Airlangga, Surabaya, Indonesia \\ faried-edfst.unair.ac.id
}

\begin{abstract}
Supplier evaluation activities play a key role in the organization because they can significantly reduce the price of goods and increase company competitiveness. On the other side demands for aspects of quality, delivery time, and costs in increasingly globalized market competition add to the complexity of supplier selection decisions.

This research proposes to build a mobile-based decision support system of supplier evaluation using VlseKriterijumska Optimizacija I Kompromisno Resenje (VIKOR) method. VIKOR method focuses on ranking by compromising from existing alternative results. The system will produce output in the form of supplier evaluation rankings and will use as a recommendation for management to assist supplier evaluation. Evaluation results show that the system is useful and suit for the users.
\end{abstract}

Keywords-Decision Support System, Supplier evaluation, VIKOR

\section{Introduction}

Supply chain management is an approach to efficient integration between suppliers, manufacturers, distribution centers, wholesalers, retailers and end consumers, where products are produced and distributed in the right amount, location the right and the right time in order to minimize the cost system and increase the level of service satisfaction. The successful implementation of supply chain management is determined first by supplier selection strategic decisions [1]. Supplier development is one of the ways that can be taken to increase the competitiveness of the entire supply chain [2], [3]. Suppliers performance will affect the company's performance. Therefore, the company needs to assess its suppliers precisely. Suppliers Selection is a strategic activity, especially for important and long-run suppliers.

Supplier selection process preceded the process of assessment of the supplier's performance. In suppliers selection, there are two aspects that companies usually consider, namely subjective aspects and objective aspects [4]. The objective of the aspect can be seen in delivery performance, price, availability, technical capabilities, and financial conditions of the supplier. Subjective factors involve company communication, services provided by suppliers, responses in goods demand, smooth delivery of goods, 
timeliness of delivery of goods, supplier vehicles, and information about supplier legality [5].To evaluate the supplier's performance requires time and effort since most companies do it by manually [6]. Based on this problem, it is necessary to do a study and improvement of the current method as a solution to multi-criteria decision making (MCDM). Several MCDM methods can be implemented into a system to select the best supplier, one of which is VIKOR. VIKOR is one of MADM method that is looking at solutions/ alternatives nearby as an approximation to the ideal solution in the rankings [7]. VIKOR has advantages in compromising alternatives, and can complete the decision making is discrete criteria of conflicting and non-commensurable, i.e., the difference unit among criteria [7] but VIKOR also has drawbacks, such as the direct weighting without considering its consistency.

In the previous study, some criteria applied were product quality, on-time delivery, price, service [8][9]. However, based on interviews with related companies, some other criteria such as packaging quality, consistency of product availability, transportation services, and response to the complaint were also used in supplier assessment. This study will use all criteria above and implement it in a mobile application to provide easy access to the company and its management.

\section{Background}

In this research, there are several reviews of the literature used: Decision Support System, Multi-Criteria Decision Making, Supplier Selection Concepts, VIKOR.

\subsection{Decision support system}

Decision Support System (DSS) is a computer-based interactive application that combines data and mathematical models to assist the decision-making process in handling a problem [10]. According to [11] there are several characteristics of DSS as follows: Assisting the decision making the process, Working by combining models and analysis techniques by entering existing data and information-seeking functions. Made using a user-friendly form. Made with flexibility and high adaptability to adapt to various changes in the environment and user needs. The possibility of intuition and personal judgment of decision-makers to be used as a basis for decision making. DSS has developed various methods that can be used to assist management in strategic fields such as academics fields [12], [13], culinary [14], [15], tourism [16]-[19], automotive [20], and many more.

\subsection{Multi-criteria decision making}

Multiple Criteria Decision Making (MCDM) is one of the most widely used methods in decision making. MCDM aims to choose the best alternative from several exclusive alternatives that are mutually beneficial based on general performance in various criteria or attributes determined by decision-makers [21]. There are two basic approaches to 
the MCDM problem, namely Multiple Attribute Decision Making (MADM) and Multiple Objective Decision Making (MODM). MADM makes decisions by considering several attributes that are sometimes conflicting. In MODM, the number of alternatives is unlimited, and reciprocity between criteria is described using sustainable functions [22]. MCDM has various methods used to solve problems in the fields of science, business, and government [23]. The MCDM methods are grouped as follows:

1) A method based on quantitative measurement or multiple criteria utility theory (MCUT). Examples of methods included in this group are TOPSIS and Simple Additive Weighting (SAW).

2) A method based on initial qualitative measurements. Examples of methods included in this group are Analytical Hierarchy Process (AHP) and Fuzzy set theory methods.

3) Preference comparison method based on the comparison of alternative pairs. Examples of methods included in this group are ELECTREE and PROMETHEE.

4) A Method based on qualitative measurements that are not converted to quantitative variables. This group includes decision-making methods in linguistic data and data usage qualitative involving a high level of uncertainty. Examples of commonly used MCDM settlement methods are TOPSIS, VIKOR, AHP, and Outranking methods (ELECTRE, PROMETHEE, ORESTE).

\subsection{Supplier selection concept}

Supplier is the party that provides suppliers of goods or services. The decision of supplier selection is an essential matter of company production activities. The right selection will bring benefits to the company, but the opposite will result in the loss of the company. According [24], supplier selection is the process of getting the right supplier who can provide fast goods or services, at the right price, at the right time and amount and the quality guaranteed to the buyer. The purpose of selecting suppliers is to reduce purchasing risk, provide optimal value to build long-term relationships between buyers and suppliers. Supplier selection process starts from the need for a supplier, and then determines and formulates decision criteria, pre-qualifies, selects the final supplier, and monitors selected suppliers.

Supplier evaluation is the process of finding potential suppliers and meeting the requirements or criteria set by the company, so the company can choose and determine suppliers that can work together for the long term.

\subsection{VIKOR method}

The VIKOR method focuses on ranking and choosing from a set of samples with different criteria, which can help decision-makers to get final decisions [7]. This method is advantageous in situations where decision-makers cannot make choices during the initial design of a system. There are five steps in determining compromise ranking using the VIKOR method. The ranking steps are as follows: 
1) Arrange criteria and alternatives into a matrix. In this step each criterion and alternative is arranged in the form of an F matrix, Ai declares the ith alternative, for $\mathrm{i}=$ $1,2,3, \mathrm{n}$; Cxn states the jth criteria, for $\mathrm{j}=1,2,3, \mathrm{~m} . \mathrm{w}_{\mathrm{j}}$ is the relative weight given to each criterion.

$$
F=\begin{gathered}
A_{1} \\
A_{2} \\
\vdots \\
A_{m}
\end{gathered}\left[\begin{array}{cccc}
C_{x 1} & C_{x 2} & \ldots & C_{x n} \\
x_{11} & x_{12} & \ldots & C_{1 n} \\
x_{21} & x_{22} & \ldots & C_{2 n} \\
\vdots & \vdots & & \vdots \\
x_{m 1} & x_{m 2} & \ldots & C_{m n}
\end{array}\right]
$$

Then the matrix is normalized by the following equation:

$$
F=\left[f_{i j}\right]_{m \times n}
$$

whereas, $f_{i j}$ stated as follows:

$$
f_{i j}=\frac{x_{i j}}{\sqrt{\sqrt{\sum_{i=1}^{m} x_{i j}^{2}}}}, i=1,2, \ldots, m
$$

$x_{i j}$ is the value of alternative Ai to the $\mathrm{j}^{\text {th }}$ criteria

2) Determining positive and negative values as ideal solutions for each criterion. Positive fi* $\mathrm{a}$ is the highest value of a criterion considered the best, while negative $f_{i}^{-}$ is the lowest value of a criterion that is considered the worst, with $\mathrm{i}=1,2, \ldots, \mathrm{n}$. The equation as follows:

$$
\begin{aligned}
A^{*} & =\left\{f_{1}^{*}, f_{2}^{*}, \ldots, f_{n}^{*}\right\} \\
A^{-} & =\left\{f_{1}^{-}, f_{2}^{-}, \ldots, f_{n}^{-}\right\}
\end{aligned}
$$

3) Calculate the utility measures $S_{i}$ and $R_{i}$ as the highest solution and the lowest solution for each alternative, with $\mathrm{i}=1,2, \ldots, \mathrm{n}$. The equation as follows:

$$
\begin{array}{r}
S_{i}=\sum_{j=1}^{m} W_{j}\left|f_{j}^{*}-f_{k j}\right| /\left|f_{j}^{*}-f_{j}^{-}\right| \\
R_{i}=\max _{j}\left\{w_{j}\left|f_{j}^{*}-f_{k j}\right| /\left|f_{j}^{*}-f_{j}^{-}\right|\right\}
\end{array}
$$

4) Calculate VIKOR index $Q_{i}$, with $\mathrm{i}=1,2, \ldots, \mathrm{n}$. The equation as follows:

$$
\begin{array}{r}
Q_{i}=\left[v \frac{S_{i}-S^{*}}{S^{-}-S^{*}}\right]+\left[(1-v) \frac{R_{i}-R^{*}}{R^{-} R^{*}}\right] \\
\mathrm{S}^{*}=\min _{i}\left(S_{i}\right), S^{-}=\max _{i}\left(S_{i}\right) \\
R^{*}=\min _{i}\left(R_{i}\right), R^{-}=\max _{i}\left(R_{i}\right)
\end{array}
$$

$\mathrm{V}$ represents weights ranging from 0-1 (generally worth 0.5 ). Smaller VIKOR index value (Qi) will produce a better alternative solution. 
5) Calculating alternative ranking. After Qi is calculated, there will be three kinds of ranking, namely Si, Ri, and Qi. A compromise solution can be seen in Qi. Alternative ranking can be checked using the following conditions:

a Condition 1: Accepted if $\mathbf{Q}(\boldsymbol{A 2})-\mathbf{Q}(\boldsymbol{A 1}) \geq \mathbf{D Q}$ with $\mathbf{D Q}=\mathbf{1} /(\boldsymbol{n}-\mathbf{1})$. A1 is the first order alternative in Qi ranking, A2 is the second-order alternative in Qi ranking.

b Condition 2: Accepted by looking at the stability of alternative ranking. Alternative stability of ranking is tested with the value of $\mathrm{v}>0.5$, or $\mathrm{v} \approx 0.5$, or $\mathrm{v}<0.5$.

If one of the conditions is not met, then a compromise solution can be proposed as follows:

- * Choose alternatives A1 and A2, only if the second condition is not reached, or

- * Choose alternative A1, A2, ..., An. If the first condition is not reached. An is an alternative determined by using the equation: $\mathbf{Q}(\boldsymbol{A n})-\mathbf{Q}(\boldsymbol{A 1})$ $<\mathbf{D Q}$ with $\mathbf{D Q}=\mathbf{1} /(\mathbf{n}-\mathbf{1})$.

\section{Implementation of The System}

Supplier evaluation is carried out annually by two different departments, which is the purchasing department, and the Quality Control (QC) department. The purchasing department assesses the Consistency of Goods Availability, Transport Services, Sales Services, and Products / Material Prices, while the QC department evaluates Packaging Quality, Product / Material Quality, On-Time Delivery, and Response to Complaints. The app's users assess by selecting the supplier name and goods supplied by the supplier, then filling in the value of each attribute with a range between 1-10, the assessment page can be seen in fig. 1 and fig. 2 . The weight of each criterion obtained from the interviews with company experts; the interview results about the weight of each criterion can be seen in table 1 .

Table 1. Criteria and its weight

\begin{tabular}{|c|l|c|}
\hline Variable & \multicolumn{1}{|c|}{ Criteria } & Weight(\%) \\
\hline C1 & Material Packaging Quality & 15 \\
\hline C2 & Product/Material Quality & 20 \\
\hline C3 & On-Time Delivery & 10 \\
\hline C4 & Consistency Of Availability Of Goods & 15 \\
\hline C5 & Transport Services & 10 \\
\hline C6 & Sales Service & 5 \\
\hline C7 & Response To Complaints / Returns & 5 \\
\hline C8 & Product / Material Prices & 20 \\
\hline
\end{tabular}


Paper-Mobile Based Decision Support System of Supplier Evaluation

Welcome, Arthur (Purchasing Department)

三 Supplier Assesment for Year 2019

Supplier
Goods

Fig. 1. Purchasing department assessment page

Welcome, Barry (QC Department)

$\equiv$ Supplier Assesment for Year 2019
Supplier Asia Polymer
Goods
Material Packaging Quality Sheet / Curtain
Product/Material Quality
On Time Delivery
Transport Services
Sales Service
Response To Complaints / Material Prices

Fig. 2. QC department assessment page 
For example, the assessment of 4 suppliers with eight criteria is shown in table 2. Based on the table, then the normalization matrix is calculated using formula (1) and (2).

Table 2. Assesment of 4 suppliers

\begin{tabular}{|c|c|c|c|c|c|c|c|c|c|}
\hline \multirow[t]{2}{*}{ Alternative } & \multicolumn{8}{|c|}{ Score } & \multirow{2}{*}{$\begin{array}{l}\text { Total } \\
\text { Score } \\
\end{array}$} \\
\hline & $C 1$ & $C 2$ & C3 & $C 4$ & $C 5$ & C6 & $C 7$ & $C 8$ & \\
\hline Asia Polymer & 9 & 9 & 9 & 10 & 9 & 8 & 10 & 9 & 73 \\
\hline Indohome & 10 & 7 & 8 & 10 & 10 & 8 & 9 & 8 & 70 \\
\hline CV.Tekad Jaya & 8 & 7 & 9 & 9 & 8 & 7 & 9 & 8 & 65 \\
\hline CoEd & 8 & 8 & 8 & 9 & 8 & 9 & 8 & 9 & 67 \\
\hline
\end{tabular}

The max and minimum values for each column of the normalized table are used to find the utility measure. The results can be seen in table 3 .

Table 3. Normalization

\begin{tabular}{|l|c|c|c|c|c|c|c|c|}
\hline \multirow{2}{*}{ Alternatives } & \multicolumn{9}{c|}{ Score } \\
\cline { 2 - 10 } & $\boldsymbol{C 1}$ & $\boldsymbol{C 2}$ & $\boldsymbol{C 3}$ & $\boldsymbol{C 4}$ & $\boldsymbol{C 5}$ & $\boldsymbol{C 6}$ & $\boldsymbol{C 7}$ & $\boldsymbol{C 8}$ \\
\hline Asia Polymer & 0.51 & 0.58 & 0.53 & 0.53 & 0.51 & 0.50 & 0.55 & 0.53 \\
\hline Indohome & 0.57 & 0.45 & 0.47 & 0.53 & 0.57 & 0.50 & 0.50 & 0.47 \\
\hline CV.Tekad Jaya & 0.46 & 0.45 & 0.53 & 0.47 & 0.46 & 0.44 & 0.50 & 0.47 \\
\hline CoEd & 0.46 & 0.51 & 0.47 & 0.47 & 0.46 & 0.56 & 0.44 & 0.53 \\
\hline Max & 0.57 & 0.58 & 0.53 & 0.53 & 0.57 & 0.56 & 0.55 & 0.53 \\
\hline Min & 0.46 & 0.45 & 0.47 & 0.47 & 0.46 & 0.44 & 0.44 & 0.47 \\
\hline
\end{tabular}

The utility measure is obtained from the calculation of the highest solution value $\left(S_{k}\right)$ and the lowest solution value $\left(R_{k}\right)$ for each alternative. Suppose that $\mathrm{U}_{\mathrm{ij}}$ utility of $\mathrm{i}^{\text {th }}$ row and $\mathrm{j}^{\text {th }}$ column, which is obtained by multiplying the normalization matrix with its weight from table 1 , then the utility value can be seen in table 4 .

Table 4. Normalization matrix multiplied by the weight

\begin{tabular}{|l|c|c|c|c|c|c|c|c|}
\hline \multirow{2}{*}{ Alternative } & \multicolumn{9}{|c|}{ Value } \\
\cline { 2 - 10 } & $\boldsymbol{C 1}$ & $\boldsymbol{C 2}$ & $\boldsymbol{C 3}$ & $\boldsymbol{C 4}$ & $\boldsymbol{C 5}$ & $\boldsymbol{C 6}$ & $\boldsymbol{C} 7$ & $\boldsymbol{C} \boldsymbol{8}$ \\
\hline Asia Polymer & 0.075 & 0 & 0 & 0 & 0.05 & 0.025 & 0 & 0 \\
\hline Indohome & 0 & 0.2 & 0.1 & 0 & 0 & 0.025 & 0.025 & 0.2 \\
\hline CV.Tekad Jaya & 0.15 & 0.2 & 0 & 0.15 & 0.1 & 0.05 & 0.025 & 0.2 \\
\hline CoEd & 0.15 & 0.1 & 0.1 & 0.15 & 0.1 & 0 & 0.05 & 0 \\
\hline
\end{tabular}

Based on table 4 , the highest solution value $\left(S_{i}\right)$ and the lowest solution value $\left(R_{i}\right)$ for each alternative are calculated by equations (5) and (6). The calculation of the $S$ value of each alternative as follows:

$$
\begin{aligned}
& \mathrm{S}_{11}=\left(\mathrm{U}_{11}+\mathrm{U}_{12}+\mathrm{U}_{13}+\mathrm{U}_{14}+\mathrm{U}_{15}+\mathrm{U}_{16}+\mathrm{U}_{17}+\mathrm{U}_{18}\right)=0.075+0+0+0+0.05 \\
& +0.025+0+0=0.15
\end{aligned}
$$




$$
\begin{aligned}
& \mathrm{S}_{21}=\left(\mathrm{U}_{21}+\mathrm{U}_{22}+\mathrm{U}_{23}+\mathrm{U}_{24}+\mathrm{U}_{25}+\mathrm{U}_{26}+\mathrm{U}_{27}+\mathrm{U}_{28}\right)=0+0.2+0.1+0+0+ \\
& 0.025+0.025+0.2=0.55 \\
& \mathrm{~S}_{31}=\left(\mathrm{U}_{31}+\mathrm{U}_{32}+\mathrm{U}_{33}+\mathrm{U}_{34}+\mathrm{U}_{35}+\mathrm{U}_{36}+\mathrm{U}_{37}+\mathrm{U}_{38}\right)=0.15+0.2+0+0.15+ \\
& 0.1+0.05+0.025+0.2=0.875 \\
& \mathrm{~S}_{41}=\left(\mathrm{U}_{41}+\mathrm{U}_{42}+\mathrm{U}_{43}+\mathrm{U}_{44}+\mathrm{U}_{45}+\mathrm{U}_{46}+\mathrm{U}_{47}+\mathrm{U}_{48}\right)=0.15+0.1+0.1+0.15 \\
& +0.1+0+0.05+0=0.65
\end{aligned}
$$

The calculation of the $\mathrm{R}$ value of each alternative is as follows:

$$
\begin{aligned}
& \mathrm{R} 11=\operatorname{Max}(\mathrm{U} 11, \mathrm{U} 12, \mathrm{U} 13, \mathrm{U} 14, \mathrm{U} 15, \mathrm{U} 16, \mathrm{U} 17, \mathrm{U} 18)=\operatorname{Max}(0.075, \\
& 0,0,0,0.05,0.025,0,0)=0.075 \\
& \mathrm{R} 21=\operatorname{Max}(\mathrm{U} 21, \mathrm{U} 22, \mathrm{U} 23, \mathrm{U} 24, \mathrm{U} 25, \mathrm{U} 26, \mathrm{U} 27, \mathrm{U} 28)=\operatorname{Max}(0,0.2, \\
& 0.1,0,0,0.025,0.025,0.2)=0.2 \\
& \mathrm{R} 31=\operatorname{Max}(\mathrm{U} 31, \mathrm{U} 32, \mathrm{U} 33, \mathrm{U} 34, \mathrm{U} 35, \mathrm{U} 36, \mathrm{U} 37, \mathrm{U} 38)=\operatorname{Max}(0.15,0.2 \\
& 0,0.15,0.1,0.05,0.025,0.2)=0.2 \\
& \mathrm{R} 41=\operatorname{Max}(\mathrm{U} 41, \mathrm{U} 42, \mathrm{U} 43, \mathrm{U} 44, \mathrm{U} 45, \mathrm{U} 46, \mathrm{U} 47, \mathrm{U} 48)=\operatorname{Max}(0.15,0.1 \\
& 0.1,0.15,0.1,0,0.05,0)=0.15
\end{aligned}
$$

The VIKOR index value (Q) is obtained by equation (7), then sorted from the smallest. To calculate the VIKOR index value of each alternative, it is necessary to calculate the maximum and minimum values of each utility measure first. The maximum value of $\mathrm{S}$ is denoted by $S^{-}$. The minimum value of $\mathrm{S}$ is denoted by $S^{*}$. Calculation of maximum and minimum values of $S$ values are:

$$
\begin{aligned}
& S^{-}=\operatorname{Max}(\mathrm{S} 11, \mathrm{~S} 21, \mathrm{~S} 31, \mathrm{~S}, 41)=\operatorname{Max}(0,15,0,55,0,875,0,65)=0,875 \\
& S^{*}=\operatorname{Min}(\mathrm{S} 11, \mathrm{~S} 21, \mathrm{~S} 31, \mathrm{~S}, 41)=\operatorname{Min}(0,15,0,55,0,875,0,65)=0,15
\end{aligned}
$$

The maximum value of $\mathrm{R}$ is denoted by $R^{-}$. The minimum value of $\mathrm{R}$ is denoted by $S^{*}$. Calculation of maximum and minimum values of $\mathrm{R}$ values are:

$$
\begin{aligned}
& R^{-}=\operatorname{Max}(\mathrm{R} 11, \mathrm{R} 21, \mathrm{R} 31, \mathrm{R}, 41)=\operatorname{Max}(0,075,0,2,0,2,0,15)=0,2 \\
& R^{*}=\operatorname{Min}(\mathrm{R} 11, \mathrm{R} 21, \mathrm{R} 31, \mathrm{R}, 41)=\operatorname{Min}(0,075,0,2,0,2,0,15)=0,075
\end{aligned}
$$

The next step is to calculate the VIKOR index value from each alternative using equation (7). The maximum strategy weight of the utility group (v) is 0.5 . The calculation of the VIKOR index value for each alternative is:

$$
\begin{aligned}
\mathrm{Q} 1=\left[v \frac{S_{11}-S^{*}}{S^{-}-S^{*}}\right]+\left[(1-v) \frac{R_{11}-R^{*}}{R^{-}-R^{*}}\right]= & =\left[0,5 \frac{0,15-0,15}{0,875-0,15}\right]+[(1- \\
\left.0,5) \frac{0,075-0,075}{0,2-0,075}\right] & =0
\end{aligned}
$$




$$
\begin{aligned}
& \mathrm{Q} 2=\left[v \frac{S_{21}-S^{*}}{S^{-}-S^{*}}\right]+\left[(1-v) \frac{R_{21}-R^{*}}{R^{-}-R^{*}}\right]=\left[0,5 \frac{0,55-0,15}{0,875-0,15}\right]+[(1- \\
& \begin{array}{c}
\left.0,5) \frac{0,2-0,075}{0,2-0,075}\right]=0,775 \\
\mathrm{Q} 3=\left[v \frac{S_{31}-S^{*}}{S^{-}-S^{*}}\right]+\left[(1-v) \frac{R_{31}-R^{*}}{R^{-}-R^{*}}\right]=\left[0,5 \frac{0,975-0,15}{0,875-0,15}\right]+[(1- \\
\left.0,5) \frac{0,2-0,075}{0,2-0,075}\right]=1 \\
\mathrm{Q} 4=\left[v \frac{S_{21}-S^{*}}{S^{-}-S^{*}}\right]+\left[(1-v) \frac{R_{21}-R^{*}}{R^{-}-R^{*}}\right]=\left[0,5 \frac{0,65-0,15}{0,875-0,15}\right]+[(1-
\end{array} \\
& \left.0,5) \frac{0,15-0,075}{0,2-0,075}\right]=0,644
\end{aligned}
$$

Supplier evaluation ranking results are obtained by sorting alternatives based on the VIKOR index value; the ranking result can be seen in Table 5.

Table 5. Supplier ranking result

\begin{tabular}{|l|c|c|c|c|c|c|c|c|c|}
\hline \multirow{1}{*}{ Alternative } & \multicolumn{10}{|c|}{ Value } & \multirow{2}{*}{$\begin{array}{c}\text { VIKOR } \\
\text { Index(Q) }\end{array}$} \\
\cline { 2 - 11 } & $\boldsymbol{C 1}$ & $\boldsymbol{C 2}$ & $\boldsymbol{C 3}$ & $\boldsymbol{C 4}$ & $\boldsymbol{C 5}$ & $\boldsymbol{C 6}$ & $\boldsymbol{C 7}$ & $\boldsymbol{C 8}$ & 0 \\
\hline Asia Polymer & 9 & 9 & 9 & 10 & 9 & 8 & 10 & 9 & 0 \\
\hline Indohome & 10 & 7 & 8 & 10 & 10 & 8 & 9 & 8 & 0,644 \\
\hline CV.Tekad Jaya & 8 & 7 & 9 & 9 & 8 & 7 & 9 & 8 & 0,775 \\
\hline CoEd & 8 & 8 & 8 & 9 & 8 & 9 & 8 & 9 & 1 \\
\hline
\end{tabular}

A compromise solution from alternative ranking can be proposed with two conditions, namely Acceptable advantage and Acceptable stability in decision making. The Acceptable advantage condition is proven by comparing the value of the difference between the second alternative VIKOR index and the first ranked alternative VIKOR index with the DQ value. Acceptable advantage conditions will be fulfilled if the difference value is greater or equal to the DQ.

$$
\begin{gathered}
\mathrm{DQ}=\frac{1}{(J-1)}=\frac{1}{(4-1)}=0,333 \\
Q(A(2))-Q(A(1))=0,644-0=0,644
\end{gathered}
$$

Because the difference value is greater than the DQ value, so the Acceptable advantage condition is fulfilled.

The second condition is the stability of the compromise solution proposed in the decision-making process, which can be: "voting by majority rule" (when v>0.5), or "by consensus" ( $\mathrm{v} \approx 0.5)$, or "with veto" $(\mathrm{v}<0.5)$. To prove the second condition, it is necessary to rank the alternative by changing the $\mathrm{v}$ value to less than $0.5(\mathrm{v}<0.5)$ and more than $0.5(v>0.5)$. In this study, we set $v=0.4$ and $v=0.6$. Both $v$ 's show the same result as Q; it proved that the second condition is fulfilled.

Based on the results, it is known that both conditions are fulfilled and Asia Polymer is proposed to be the best compromise solution. Fig. 3 and fig. 4 below show supplier recommendation result based on goods and its detail. 

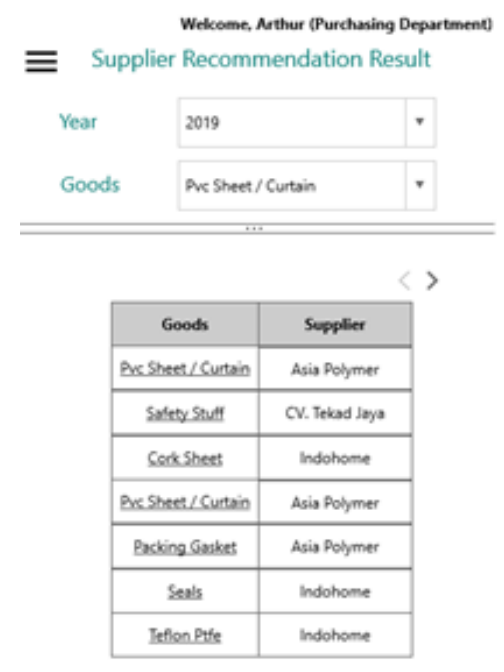

Fig. 3. Supplier ranking page

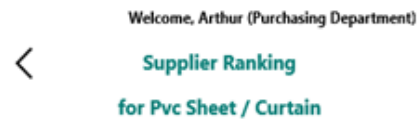

for Pvc Sheet / Curtain
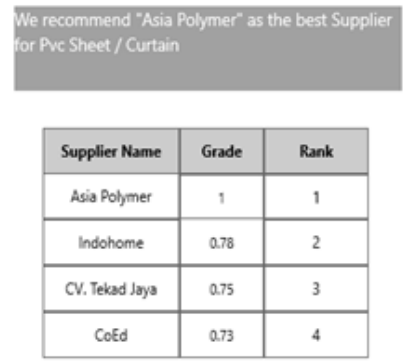

Fig. 4. Supplier ranking page

\subsection{System evaluation}

Mean Opinion Score (MOS) is a numerical measure of the human-judged overall quality of an event or experience. MOS is the arithmetic mean of all values on a predetermined scale to represent the subject's opinion about the quality of the system [25]. MOS is expressed in one rational number, generally on a scale of 1-5, where one is the worst and five are the best. The MOS scale can change depending on the needs of the evaluation carried out. MOS is calculated as an arithmetic mean, so the MOS formula is as follows :

$$
\operatorname{MOS}=\frac{\sum_{n=0}^{N} R_{n}}{N}
$$


In this research, MOS used to evaluate the system by giving questionnaires to users. Calculations are performed on each category by giving a score with a certain weight, namely: strongly agree $(\mathrm{SA})=4$, agree $(\mathrm{A})=3$, disagree $(\mathrm{D})=2$, and strongly disagree $(\mathrm{SD})=1$. From the results of the evaluation, Mean Opinion Score (MOS) will be obtained from each factor. From 30 system users, MOS ratings were obtained as in table 6.

Table 6. Evaluation of Each Category

\begin{tabular}{|c|c|c|c|c|c|c|c|}
\hline Category & Factor & SA & $\mathbf{A}$ & D & SD & MOS & $\begin{array}{c}\text { MOS each } \\
\text { category }\end{array}$ \\
\hline \multirow[t]{4}{*}{ Usability } & The system is easy to use & 20 & 10 & 0 & 0 & 3,6 & \multirow{4}{*}{3.5} \\
\hline & The system is easy to understand & 10 & 20 & 0 & 0 & 3,3 & \\
\hline & The application is running well & 20 & 10 & 0 & 0 & 3,6 & \\
\hline & $\begin{array}{l}\text { The language used by the system is easy to } \\
\text { understand }\end{array}$ & 20 & 10 & 0 & 0 & 3,6 & \\
\hline $\begin{array}{l}\text { Functional } \\
\text { Completeness }\end{array}$ & The input used is easy to enter and understand & 10 & 20 & 0 & 0 & 3,3 & 3.3 \\
\hline Performance & The system provides a fast response & 30 & 0 & 0 & 0 & 3 & 3 \\
\hline \multirow[t]{2}{*}{ Overall } & $\begin{array}{l}\text { The output of the system built can help in evalu- } \\
\text { ating the company's supplier }\end{array}$ & 0 & 30 & 0 & 0 & 3 & \multirow[t]{2}{*}{3.15} \\
\hline & The system is made good in its entirety & 10 & 20 & 0 & 0 & 3,3 & \\
\hline
\end{tabular}

The MOS results of each category are then calculated using equation (8). So that the overall system score is obtained. The calculation for the overall system score is as follows:

System score $=(3.5+3.3+3+3.15) / 4=3.23$

Based on the evaluation system that gives a value of 3.23 of the total value of 4 , it can be concluded that the system is useful and can be accepted by the users.

\section{Conclusion and Future Work}

The mobile decision support system of a supplier evaluation can help a company in the supplier selection process. The system used VIKOR as a ranking method because it can compromise the existing alternatives, normalize the process that needed to produce the alternative ranking, and obtain results that close to an ideal solution. The assessment use eight criteria which evaluated by two different departments, namely the purchasing department, which evaluate the consistency of goods, transportation services, sales services, product/material prices, and the QC department which evaluates the quality of packaging material, product quality/material, on-time delivery, and responses to complaints. The evaluation of the system shows that the system is useful, which proven by the users that gave MOS grade 3.32 of 4 . For further research, it is recommended to use different weighting methods and graphics enhancements. It is also recommended that the number of criteria can be changed based on the user's preference. 


\section{$5 \quad$ References}

[1] D. Amila, S. Samarasinghe, J. E. Tookey, J. Olabode, B. Rotimi, and S. Thiruchelvam, "Supplier Selection in the Construction Material Purchasing Function," 4th Annu. Am. Bus. Res. Conf., pp. 1-14, 2006.

[2] E. K. Lee, S. Ha, and S. K. Kim, "Supplier selection and management system considering relationships in supply chain management," IEEE Trans. Eng. Manag., vol. 48, no. 3, pp. 307-318, 2001. https://doi.org/10.1109/17.946529

[3] D. Utama, T. Djatna, E. Hambali, M. Marimin, and D. Kusdiana, "Sistem penunjang keputusan cerdas untuk pencarian jalur optimum rantai pasok bioenergi berbasis kelapa sawit dengan menggunakan metode optimasi koloni semut," J. Teknol. Ind. Pertan., vol. 21, no. 1, pp. 50-62, 2011. https://doi.org/10.22146/agritech.12528

[4] E. Delbufalo, "Subjective trust, perceived risk and exchange performance in buyer- supplier relationships," Italia, 10, 2012.

[5] E. Ambrose, D. Marshall, B. Fynes, and D. Lynch, "Communication media selection in buyer-supplier relationships," Int. J. Oper. Prod. Manag., vol. 28, no. 4, pp. 360-379, 2008. https://doi.org/10.1108/01443570810861561

[6] H. J. Harrington, I. F. Schotanus, J. T. Tutor, and D. L. Van De Walle, "Design of a Supplier Performance Measurement \&amp; Evaluation System for DSM's Petrochemical \&amp; Energy Group," 2012.

[7] S. Opricovic and G. H. Tzeng, "Compromise solution by MCDM methods: A comparative analysis of VIKOR and TOPSIS," Eur. J. Oper. Res., vol. 156, no. 2, pp. 445-455, 2004. https://doi.org/10.1016/s0377-2217(03)00020-1

[8] F. Dweiri, S. Kumar, S. Ahmed, and V. Jain, "Corrigendum to 'Designing an integrate d AHP base d decision support system for supplier selection in automotive industry ' Expert Systems," Expert Syst. Appl., vol. 72, pp. 467-468, 2017. https://doi.org/10.1016/ j.eswa.2016.12.025

[9] J. Roshandel, S. S. Miri-Nargesi, and L. Hatami-Shirkouhi, "Evaluating and selecting the supplier in detergent production industry using hierarchical fuzzy TOPSIS," Appl. Math. Model., vol. 37, no. 24, pp. 10170-10181, 2013. https://doi.org/10.1016/j.apm.2013.05.043

[10] C. Vercellis, Business Intelligence: Data Mining and Optimization for Decision Making, 1st ed. John Wiley \& Sons Ltd, 2009.

[11] E. Turban, Decision Support and Business Intelligence Systems 9th. Prentice Hall Press Upper Saddle River, NJ, USA @2010, 2010.

[12] C. Fiarni, E. M. Sipayung, and P. B. T. Tumundo, "Academic Decision Support System for Choosing Information Systems Sub Majors Programs using Decision Tree Algorithm," J. Inf. Syst. Eng. Bus. Intell., vol. 5, no. 1, p. 57, 2019. https://doi.org/10.20473/jisebi.5.1.57$\underline{66}$

[13] R. Putra, I. Werdiningsih, and I. Puspitasari, "Sistem Pendukung Keputusan Pemilihan Siswa Berprestasi di Sekolah Menengah Pertama dengan Metode VIKOR dan TOPSIS," J. Inf. Syst. Eng. Bus. Intell., vol. 3, no. 2, p. 113, 2017. https://doi.org/10.20473/jisebi.3.2.113$\underline{121}$

[14] R. K. Dewi, M. T. Ananta, L. Fanani, K. C. Brata, and N. D. Priandani, "The Development of Mobile Culinary Recommendation System Based on Group Decision Support System,".

[15] R. K. Dewi, B. T. Hanggara, and A. Pinandito, "A Comparison Between AHP and Hybrid AHP for Mobile Based Culinary Recommendation System," Int. J. Interact. Mob. Technol., vol. 12, no. 1, p. 133, 2018. https://doi.org/10.3991/ijim.v12i1.7561 
[16] M. Braunhofer and F. Ricci, "Selective contextual information acquisition in travel recommender systems," Inf. Technol. Tour. https://doi.org/10.1007/s40558-017-0075$\underline{6}$

[17] H. R. Taluay, K. B. Seminar, and D. R. O. Monintja, "Development of Web - Based Tourism Decision Support System in Talaud Island Regency," vol. 39, no. 1, 2015.

[18] A. A. Taroreh, A. R. Tanaamah, and C. Fibriani, "Decision Support System Feasibility of Tourism Resort in Poso District used 360 Degree Method," Int. J. Comput. Sci. Issues, vol. 11, no. 2, pp. 201-207, 2014.

[19] I. M. A. Wirawan and I. W. B. Diarsa, "Mobile-based Recommendation System for the Tour Package Using the Hybrid Method," Int. J. Interact. Mob. Technol., vol. 12, no. 8, p. 64, 2018. https://doi.org/10.3991/ijim.v12i8.9483

[20] A. Azizi, D. O. Aikhuele, and F. S. Souleman, "A Fuzzy TOPSIS Model to Rank Automotive Suppliers," Procedia Manuf., vol. 2, no. February, pp. 159-164, 2015. https://doi.org/10.1016/j.promfg.2015.07.028

[21] G. H. Tzeng and K. Y. Shen, New Concepts and Trends of Hybrid Multiple Criteria Decision Making. New York: CRC Press Taylor \& Francis Group, 2017. https://doi.org/ $\underline{10.1201 / 9781315166650}$

[22] C. Kahraman, Fuzzy Multi-Criteria Decision Making, 1st ed. Springer, Boston, MA, 2008.

[23] E. K. Zavadskas, Z. Turskis, and S. Kildiene, "State of Art Surveys of Overviews on Mcdm/Madm Methods," Technol. Econ. Dev. Econ., vol. 20, no. 1, pp. 165-179, 2014. https://doi.org/10.3846/20294913.2014.892037

[24] Fatih Emre Boran, S. Genç, M. Kurt, and D. Akay, "A multi-criteria interval-valued intuitionistic fuzzy group decision making for supplier selection with TOPSIS method," Expert Syst. Appl., vol. 36, no. 8, pp. 11363-11368, 2009. https://doi.org/10.1016/j.eswa.2009.03.039

[25] R. C. Streijl, S. Winkler, and D. S. Hands, "Mean opinion score (MOS) revisited: methods and applications, limitations and alternatives," Multimed. Syst., vol. 22, no. 2, pp. 213-227, 2016. https://doi.org/10.1007/s00530-014-0446-1

\section{Author}

Faried Effendy is a lecturer at Information System Study Program, Universitas Airlangga, Indonesia. He is a member of the International Association of Online Engineering (IAOE), Asosiasi Perguruan Tinggi Ilmu Komputer (APTIKOM), and Indonesian Mathematical Society (IndoMS). His research interest includes Information System Engineering and Business Intelligence.

Article submitted 2019-07-24. Resubmitted 2019-08-27. Final acceptance 2019-08-29. Final version published as submitted by the authors. 